\title{
MLearning-PL: a pedagogical pattern language for mobile learning applications
}

\author{
Maria Lydia Fioravanti ${ }^{1}$ and Ellen Francine Barbosa ${ }^{1}$ \\ ${ }^{1}$ Institute of Mathematics and Computer Sciences (ICMC) \\ University of São Paulo (USP) - São Carlos (SP), Brazil \\ mlfioravanti@usp.br, francine@icmc.usp.br
}

\begin{abstract}
Mobile learning (m-learning) applications can provide several benefits to learners. However, there are still several problems to be further investigated, such as the challenge to keep the learner motivated while using the application during educational activities. The application design can help to solve this kind of problems. There is a need to understand such problems in the pedagogical level and then properly eliciting requirements that would address those problems. Pedagogical patterns try to capture expert knowledge regarding the practice of teaching and learning in a way that it is possible for others to reuse this experience. Therefore, pedagogical patterns can be a tool to assist in the design of new m-learning applications as well as to the improvement of the existing ones. Aiming to bridge this gap, a pedagogical pattern language entitled MLearning-PL has been proposed to guide the requirements elicitation of m-learning applications projects. It is composed of 14 patterns and focuses on assisting in the definition of mobile applications in order to keep learners motivated and committed to using such applications, considering their different learning styles and an effective knowledge acquisition. Experimental studies comparing MLearning-PL to an ad hoc approach in a pedagogical problem resolution scenario were conducted. The results obtained so far provided good evidences of the applicability, effectiveness and efficiency of MLearning-PL.
\end{abstract}

\section{Introduction}

Computational learning applications play a key role in educational activities, both in academia and in industry [Svetlana et al. 2009, Craig et al. 2012]. In this scenario, mobile learning (m-learning) has emerged as a new and promising learning modality, providing more interactivity and flexibility to learners, tutors and teachers in carrying out educational activities and practices [Kearney et al. 2012]. However, despite having several benefits and facilities, mobile learning applications also present problems and challenges that need to be better investigated. These problems and challenges are not limited to developmental aspects or technologies; pedagogical aspects related to this kind of application should also be considered, such as: keeping the learner motivated to avoid dropouts, dealing with different learning styles (visual, logical, social, etc.), guiding the learner in self-learning, and so forth [Economides 2008, Sarrab et al. 2013, Sharples 2013].

In a related perspective, when dealing with domain-specific software, we must be concerned about domain requirements. It is important to have expert knowledge in the requirements engineering team and, in the case of mobile learning applications projects, 
this knowledge would come from educators, teachers and tutors. However, capturing and transferring tacit knowledge is not a trivial task.

In this scenario, patterns can be important tools to guide the designers and developers of m-learning applications, contributing both to avoid the already known problems without having to rediscover them and to add quality to the software, since they are successful solutions [Gamma et al. 1995]. Patterns constitute a mechanism for capturing domain experience and knowledge to allow it to be reapplied when a new problem is encountered [Pressman and Bruce R. Maxim 2014]. Similarly, pedagogical patterns aim at capturing expert knowledge of the practice of teaching and learning [Bergin et al. 2012]. However, there is a lack of research initiatives on the use of pedagogical patterns to address the aforementioned problems.

Aiming to solve, or at least diminish, the problems related to mobile learning and considering the lack of pedagogical patterns for mobile learning applications, this work aims to establish a pedagogical pattern language for this kind of application.

The remainder of this paper is organized as follows. In Section 2, the pedagogical pattern language is presented; we also describe the process used to propose the pattern language as well as the conducted steps. Results are presented in discussed in Section 3. Finally, our conclusions and perspectives for future work are presented in Section 4.

\section{MLearning-PL}

MLearning-PL is a pedagogical pattern language for mobile learning applications, comprised of 14 patterns. It aims to assist in the definition of mobile applications for keeping learners motivated and committed to using such applications, according to their different learning styles and an effective knowledge acquisition.

The main audience of MLearning-PL is novice educators who occasionally must play a requirements analyst role in a mobile learning application project. Those educators can be benefited from MLearning-PL, once they can reuse pedagogical knowledge from senior educators.

To the best of our knowledge, there are no initiatives investigating the use of patterns to address the pedagogical issues in the context of mobile learning applications [Fioravanti et al. 2015]. MLearning-PL is a step forward towards bridging such a gap.

The work of [Meszaros and Doble 1997] provides guidelines for pattern writing, but it focuses on the patterns format and disposition of the patterns throughout the pattern language, i.e., nothing is mentioned about how to discover the patterns based on the knowledge about a particular domain, or how to organize them or to delimit their scope.

Aiming to systematize the creation of pattern languages, [Braga et al. 2007] proposed a process to create analysis pattern languages for specific domains. In a related perspective, [Iba et al. 2011] proposed a procedure for establishing a pattern language based on their experience in creating a pattern language for creative learning. We have adapted such processes to our work's needs; the resulting process is divided into six steps applied in an iterative, incremental manner. 
VII Congresso Brasileiro de Informática na Educação (CBIE 2018)

Anais dos Workshops do VII Congresso Brasileiro de Informática na Educação (WCBIE 2018)

\section{Step 1 - Domain Model Creation}

In order to gather information about the mobile learning domain, we considered the requirements catalog, namely ReqML-Catalog, proposed by [Soad et al. 2017], since it summarizes important aspects of what a mobile application should contain based on the existing systems and on expert knowledge. In the scope of our work, we only considered the pedagogical subset of requirements shown in [Fioravanti 2017, p. 66].

\section{Step 2 - Pattern Mining}

We have already found out that patterns were explored in the context of electronic learning [Fioravanti et al. 2015]. We could also verify the use of patterns for mobile learning, but not pedagogical patterns. In this sense, the idea was to retrieve the existing pedagogical patterns and analyze which ones could be used in the mobile learning context.

In order to retrieve those pedagogical patterns, a systematic mapping study (SMS) was conducted, according to Petersen et al. guidelines [Petersen et al. 2008]. This SMS was conducted considering automated search (ACM, EI Compendex, IEEE Xplore Digital Library, ISI Web of Science, Science@Direct, Scopus and Springer Link) and manual search [Fioravanti and Barbosa 2016].

We retrieved 312 different pedagogical patterns that were categorized according to ReqML-Catalog's characteristics and sub-characteristics, in order to partition the domain into several sub-domains. The results were summarized into a Catalog of Pedagogical Patterns [Fioravanti and Barbosa 2018].

\section{Step 3 - Pattern Determination}

Since we obtained a great number of pedagogical patterns, we chose to focus on a sub-domain. According to several authors [Lonsdale et al. 2005, Costabile et al. 2008, Skiba 2011], distraction is one of the most important problems in m-learning. Although mobile devices can be considered an important learning tool, they can also be considered a distraction source, due their several possibilities over the internet. In this sense, it is important to capture learners' attention, motivate and engage them in the learning experience in a didactically correct way. Considering this scenario, we chose to start the creation of MLearning-PL addressing some strongly interrelated aspects: Engagement, Motivation, Learning style and Knowledge effectiveness.

\section{Step 4 - Pattern Writing}

We adopted a table format to write the patterns variation of our pattern language, containing the following elements: ID, Name, Variant of, Context, Problem, Forces, Solution, Known Uses, Resulting Context and Related Patterns. We opted out for a more concise format, organized in a table format to provide easier understanding for the readers. Next, the pattern Let's Play is presented in order to illustrate how is the presentation format of each of the patterns that compose MLearning-PL.

\begin{tabular}{ll}
\hline $\mathbf{6}$ & Let's Play \\
\hline Variant of & Playful Learning [Iba et al. 2014] \\
\hline Context & The process of learning bores the learners. \\
\hline Problem & Learning as a duty is ineffective and painful. \\
\hline
\end{tabular}


VII Congresso Brasileiro de Informática na Educação (CBIE 2018)

Anais dos Workshops do VII Congresso Brasileiro de Informática na Educação (WCBIE 2018)

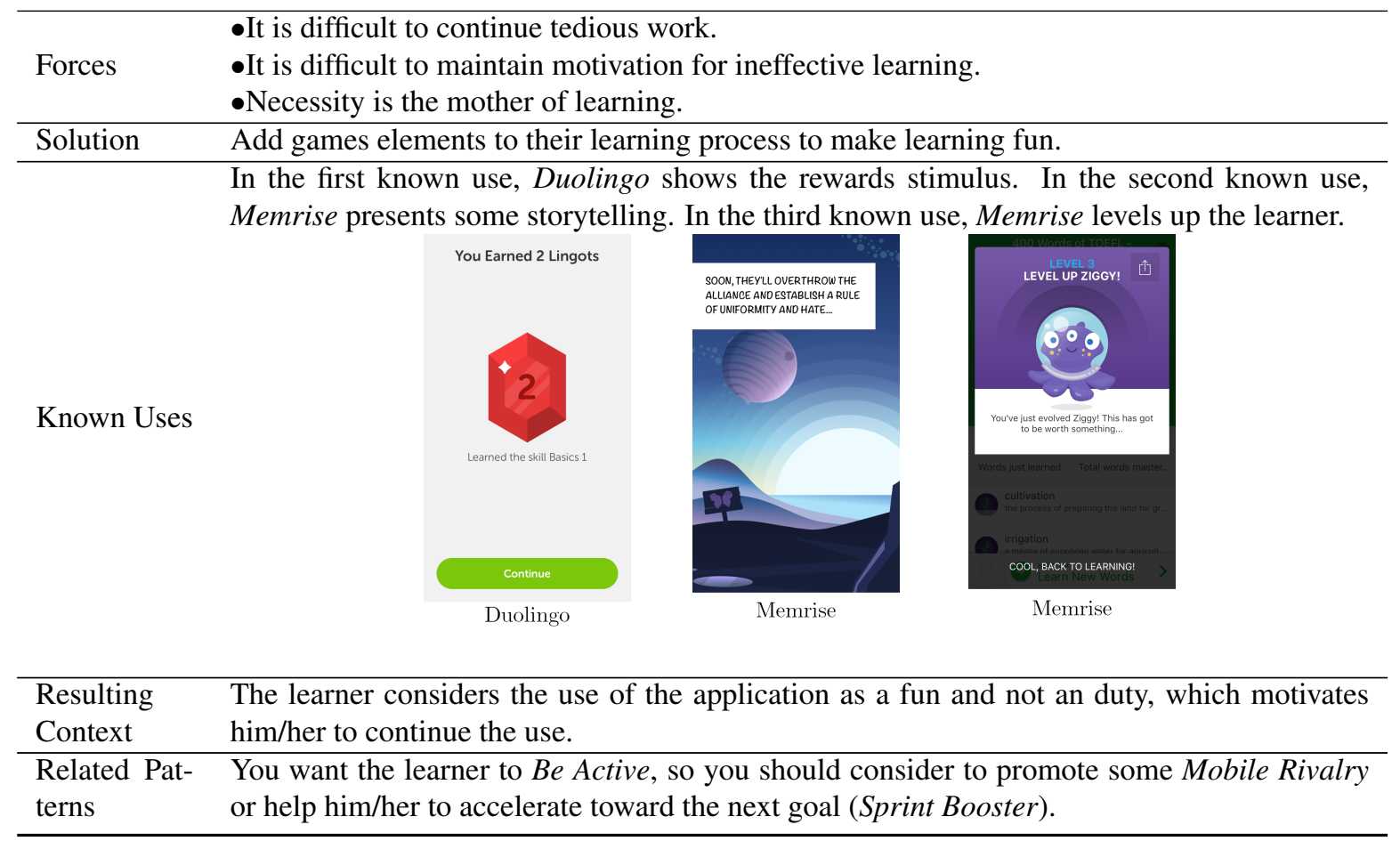

A brief description of the patterns, in the form of patlets (problem-solution pair), is presented in Table 2 .

Table 2: MLearning-PL Patlets

\begin{tabular}{|c|c|}
\hline Name & Problem-Solution Pair \\
\hline Be Active & $\begin{array}{l}\text { The deep consequences of a theory are unlikely to be obvious to one who reads about, or hears about the theory. The } \\
\text { unexpected difficulties inherent in using the theory or applying the ideas are not likely to be apparent until the theory } \\
\text { is actually used. Therefore, keep the learners active. They should be active in the app, either with questions or with } \\
\text { exercises. }\end{array}$ \\
\hline $\begin{array}{l}\text { Give Them a } \\
\text { Treat }\end{array}$ & $\begin{array}{l}\text { It is not easy to actively continue exploring and studying. Therefore, make the learners feel the strong emotion of } \\
\text { accomplishment by giving them some reward in the app, like a score or a customized message, which will motivate } \\
\text { their learning. }\end{array}$ \\
\hline $\begin{array}{l}\text { Keep } \\
\text { Posted }\end{array}$ & $\begin{array}{l}\text { It is not easy to keep the learner motivated to learn. Therefore, show the evolution of the learners at each advanced } \\
\text { stage, so they can realize how their knowledge and skills have grown. }\end{array}$ \\
\hline $\begin{array}{l}\text { Gold, Silver and } \\
\text { Bronze Medal }\end{array}$ & $\begin{array}{l}\text { Normally the reward structure is private. In grading you give the learner praise, but this loses the opportunity to } \\
\text { show other learners what you value most highly. Therefore, when a learner is doing well, or has done something } \\
\text { well, praise them publicly for it, by giving them some reward that is shown to all learners. }\end{array}$ \\
\hline Mobile Rivalry & $\begin{array}{l}\text { It is difficult to maintain efforts alone. Therefore, promote some collaborative activities among learners where they } \\
\text { compete against each other. }\end{array}$ \\
\hline Let's Play & $\begin{array}{l}\text { Learning as a duty is ineffective and painful. Therefore, add games elements to their learning process to make } \\
\text { learning fun. }\end{array}$ \\
\hline Sprint Booster & $\begin{array}{l}\text { Your motivation is faltering even though the goal is within reach. Therefore, provide small activities that allow the } \\
\text { learner to set and accelerate toward the next goal to pass through the current goal without slowing down. }\end{array}$ \\
\hline Little by Little & $\begin{array}{l}\text { If a topic takes longer than the time learners can concentrate, the learners will have difficulties understanding the topic } \\
\text { in its entirety. Therefore, organize the app activities in such a way that the topics remain small and understandable. }\end{array}$ \\
\hline Swirl & $\begin{array}{l}\text { If we try to do the topics in any logical order we tend to get bogged down in details and leave the learners bored. } \\
\text { Learners learn best when they are doing things, and meaningful problems motivate them to work harder. Therefore, } \\
\text { organize the app activities to introduce topics to learners without covering them completely at first viewing so that a } \\
\text { number of topics can be introduced early and then used. }\end{array}$ \\
\hline
\end{tabular}


VII Congresso Brasileiro de Informática na Educação (CBIE 2018)

Anais dos Workshops do VII Congresso Brasileiro de Informática na Educação (WCBIE 2018)

As Soon As Pos- Learners have difficulties sometimes distinguishing between the important and the unimportant ideas. However, sible learners often remember best what they learn first. Therefore, organize the activities in the app so that the most important topics are taught first.

\begin{tabular}{ll}
\hline $\begin{array}{l}\text { Respect the Dif- } \\
\text { ferences }\end{array}$ & $\begin{array}{l}\text { To improve learners' skills, the exercise must be located at the upper limit of the participant's current skill level, } \\
\text { but this will be different for each participant. Therefore, provide exercises of different difficulty levels, different } \\
\text { approaches and different topics to each learner, according to his/her learning style and limitations. }\end{array}$ \\
\hline Switch Thinking & $\begin{array}{l}\text { Logical thinking is not sufficient to achieve a breakthrough without intuitive thinking and vice-versa. Therefore, } \\
\text { provide activities in the app that switch learners' thinking between two modes of logical and intuitive thinking. }\end{array}$ \\
\hline Suitable for You & $\begin{array}{l}\text { Every person obtains information differently, using different sensory modalities. Some people, the visuals, learn } \\
\text { most effectively by watching; the auditories, by listening; and the kinesthetics, through action. Therefore, provide } \\
\text { different approaches and types of medias to the same topic, for instance, texts, videos, infographics, and so on. }\end{array}$ \\
& $\begin{array}{l}\text { Accept different learning styles by addressing various sensory modalities. It might be difficult to provide different } \\
\text { approaches for every single topic, but make sure to at least change the approach when you change the topic. }\end{array}$ \\
\hline Be Part of It & $\begin{array}{l}\text { Most teaching styles respect the auditories, a few the visuals, and even fewer the kinesthetics. Therefore, invite the } \\
\text { learners to behave as a part of the concept involved in a collaborative role play. Every learner plays one part of the } \\
\text { concept to get a deeper knowledge of its underlying structure. Learners see how the different parts of the concepts } \\
\text { are all working together to solve a bigger problem. }\end{array}$ \\
\hline
\end{tabular}

\section{Step 5 - Pattern Language Graph Creation}

We analyzed each of the patterns chosen for MLearning-PL, trying to capture its relations. After the choice of the patterns that would compose the language, we created a graph to show how the patterns relate to each other within the pattern language (Figure 3).

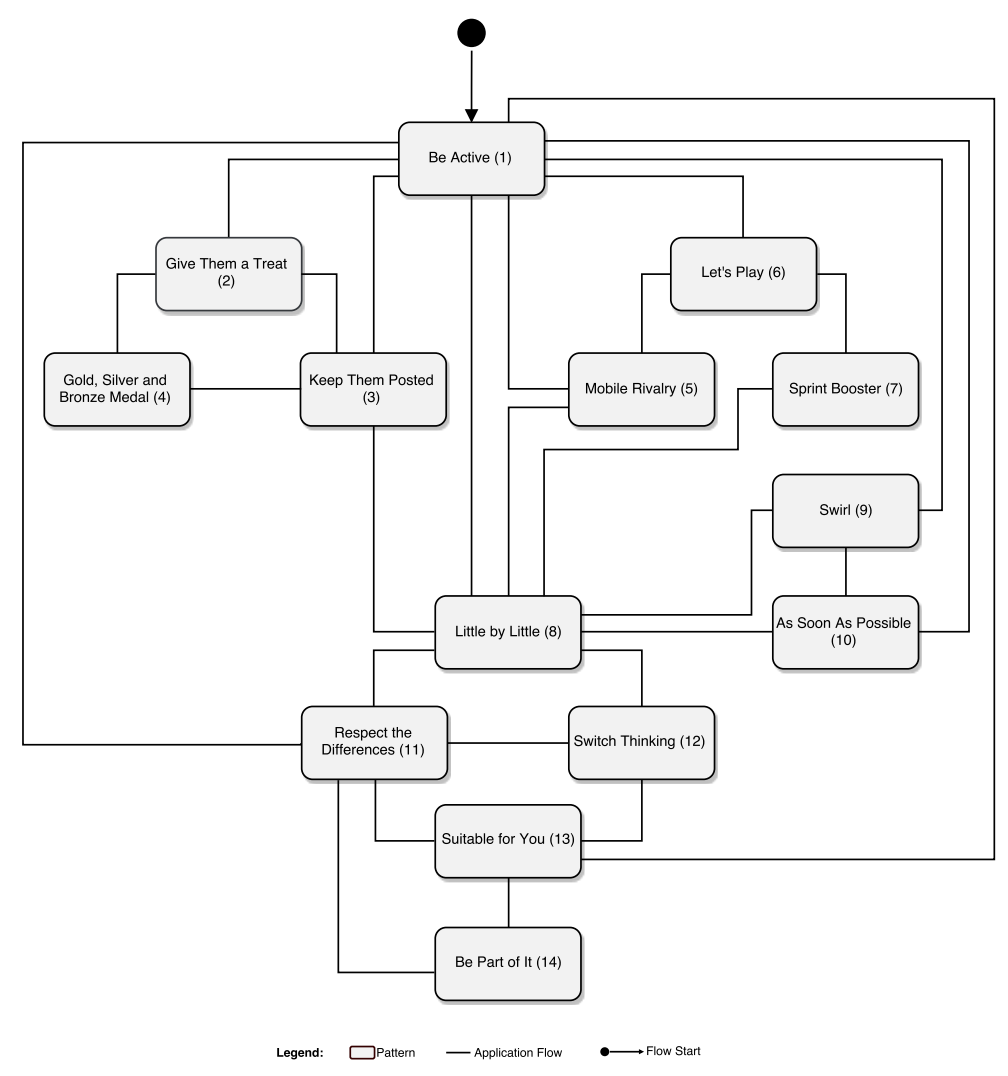

Figure 1. MLearning-PL Graph

\section{Step 6 - Pattern Language Evaluation}

Aiming to evaluate the proposed pattern language, a twofold approach was adopted: (i)conduction of an experimental study; and validation with patterns experts. 
Regarding the experimental study, it was conducted according to Wohlin et al. [Wohlin et al. 2012] guidelines. The idea was to evaluate the effectiveness, efficiency and applicability of MLearning-PL, in the context of m-learning applications requirements elicitation, in comparison to an ad hoc approach. The subjects of this experimental study were people involved in educational activities, i.e., teachers and tutors. They had to solve an activity containing different situations involving pedagogical problems (some of them using MLearning-PL as a support, and some of them using an ad hoc approach).

Regarding the validation with patterns experts, the software patterns community recommends that all pattern languages be submitted to a writers' workshop in Pattern Languages of Programs (PLoP) conferences to improve the patterns. Thus, MLearningPL was submitted to the 24th International Conference on Pattern Language of Programs 1. During our writers' workshop session, experienced pattern writers suggested some improvement points, which were considered in the evolution of the pattern language.

\section{Results and Discussion}

During the pattern language evaluation by means of the experimental study, the aim was the comparison of two different approaches for pedagogical problems solving. The research questions were formalized into the following hypotheses, so that statistical tests could be conducted:

RQ1. Does the use of MLearning-PL help educators to provide better pedagogical solutions to m-learning problems?

RQ2. Does the use of MLearning-PL lead educators to solve pedagogical problems faster?

In this sense, we aimed to evaluate the subjects' performance considering two different aspects: effectiveness and efficiency. We measured effectiveness, using three different metrics: (i) correctness - average percentage of problems solved correctly; (ii) completeness - average score of solutions' completeness; and (iii) complexity - average score of solutions' complexity. Then, we defined the metric efficiency - average time to solve all problems - to measure efficiency.

According to Table 3, considering correctness, the median of MLearning-PL $(100 \%)$ is higher than that of the ad hoc approach $(83.33 \%)$, which indicates subjects that used MLearning-PL could solve more problems correctly than those who used the ad hoc approach.

The results are similar for completeness and complexity. When MLearning-PL was used, the medians were 3.67 and 3.29 for completeness and complexity of the solutions, respectively, whereas the use of the ad hoc approach obtained 2.5. Finally, concerning the time spent on the tasks, the median for MLearning-PL is 33.41 minutes against 34.36 for the ad hoc approach.

By the analysis of the obtained data, MLearning-PL approach presented better results than the ad hoc approach, probably due the systematization introduced in the process by means of using patterns, since systematic approaches are usually better than ad hoc approaches and, particularly, because patterns can be used to solve common problems.

\footnotetext{
${ }^{1}$ http://www.hillside.net/plop/2017/
} 
VII Congresso Brasileiro de Informática na Educação (CBIE 2018)

Anais dos Workshops do VII Congresso Brasileiro de Informática na Educação (WCBIE 2018)

Table 3. Experimental Study: Measures

\begin{tabular}{|c|c|c|c|c|c|}
\hline & Subject & correctness & $\begin{array}{c}\text { Effectiveness } \\
\text { completeness }\end{array}$ & complexity & $\begin{array}{r}\text { Efficiency } \\
\text { efficiency }\end{array}$ \\
\hline \multirow{8}{*}{ 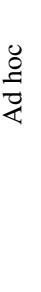 } & 1 & 100 & 3.33 & 2.83 & 47.43 \\
\hline & 2 & 33.33 & 1.75 & 1.67 & 20.35 \\
\hline & 3 & 50 & 2.08 & 2.08 & 11.61 \\
\hline & 4 & 83.33 & 2.50 & 2.50 & 39.37 \\
\hline & 5 & 100 & 3.00 & 2.75 & 38.81 \\
\hline & 6 & 100 & 2.92 & 2.83 & 34.36 \\
\hline & 7 & 50 & 2.33 & 2.08 & 26.38 \\
\hline & Median & $83.33 \%$ & 2.50 & 2.50 & 34.36 \\
\hline \multirow{9}{*}{ 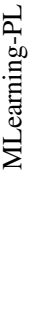 } & 8 & 100 & 4.17 & 3.75 & 35.03 \\
\hline & 9 & 83.33 & 3.58 & 3.25 & 44.53 \\
\hline & 10 & 100 & 3.92 & 3.42 & 32.77 \\
\hline & 11 & 100 & 3.33 & 2.83 & 34.04 \\
\hline & 12 & 83.33 & 3.75 & 3.33 & 23.73 \\
\hline & 13 & 100 & 3.58 & 3.25 & 42.59 \\
\hline & 14 & 100 & 4.08 & 3.75 & 28.50 \\
\hline & 15 & 66.67 & 2.58 & 2.83 & 23.57 \\
\hline & Median & $100 \%$ & 3.67 & 3.29 & 33.41 \\
\hline
\end{tabular}

We also applied a feedback questionnaire to understand the participants' perceptions about MLearning-PL on its clearness and completeness. The answers provided by the participants and their perceptions regarding the proposed activities were considered for the qualitative analysis of the results.

The subjects that used MLearning-PL were more inclined to reach a solution closer to that expected. The time spent on the solving of the problems was similar in both groups, probably because: (i) the subjects that used the ad hoc approach did not know how to answer the questions in detail and did not take longer time detailing the answer; (ii) the subjects that used MLearning-PL were more careful and analytical to answer the questions; or (iii) the use or not of an extra artifact did not influence the execution time of the task.

The participants who performed the activities with the ad hoc approach were asked if any further artifacts would be useful in the problem-solving process. Figure ?? shows that five subjects agreed and two neither agreed, nor disagreed on the usefulness of an artifact, which indicates the problem-solving activity is not trivial and may benefit from the use of additional artifacts.

The participants who used the MLearning-PL approach were asked about the pattern language used. Firstly, we asked how helpful it was to support the performed activities; most of them agreed or strongly agreed that MLearning-PL helped in the the problem-solving process (Figure 2(b)). We also asked their opinions on the completeness and clearness of the pattern language. Regarding completeness, the results were not unanimous (Figure 2(c)), i. e., 50\% (four subjects) agreed it was complete, 25\% neither agreed, nor disagreed and 25\% disagreed. Although the subjects considered MLearningPL not complete enough, they did suggest improvement points to the pattern language, such as new patterns or even modifications of the existing ones. Finally, regarding clearness (Figure 2(d)), MLearning-PL was pointed out as clear and easy to understand, since $87,5 \%$ of the subjects answered "agree". 
VII Congresso Brasileiro de Informática na Educação (CBIE 2018)

Anais dos Workshops do VII Congresso Brasileiro de Informática na Educação (WCBIE 2018)

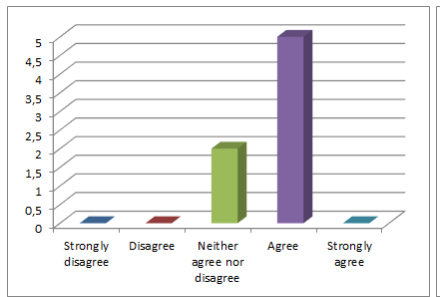

(a) Do you believe that the use of further artifacts would help in the problem-solving process?

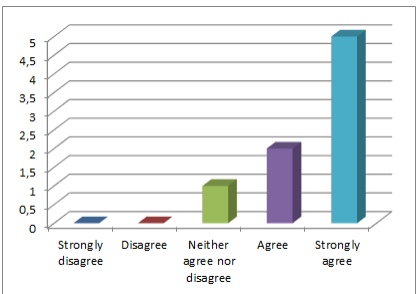

(b) Do you believe that MLearningPL helped in the process of solving pedagogical problems?

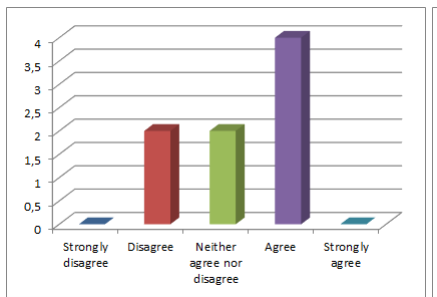

(c) Do you believe that MLearning-PL is complete?

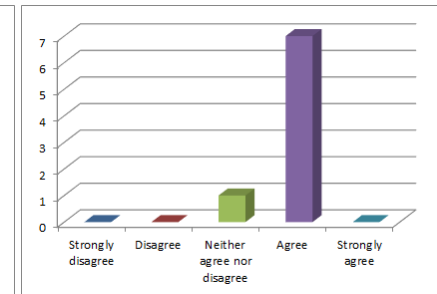

(d) Do you believe that MLearning-PL is clear and easy to understand?

Figure 2. MLearningAnswers to the feedback questionnaire

The subjects were enthusiastic and positive about MLearning-PL and its importance, which indicates positive evidences on its use to support the pedagogical problemsolving process.

\section{Conclusions and Future Work}

The main contribution of this work is the proposition of MLearning-PL, a pedagogical pattern language for mobile learning applications. To the best of our knowledge, there was no pedagogical pattern language that addresses pedagogical issues in the context of mobile learning, so MLearning-PL is a step forward in this direction aiming to bridge this gap. MLearning-PL differs from other pattern languages, particularly, because it was created and evaluated by means of a systematic process. As discussed, MLearning-PL is comprised of 14 patterns, which were mined through a systematic mapping and rewritten as variants, considering the mobile learning scenario.

The main publications resulting from our work are summarized in Table 4 .

Table 4. Main Publications

\begin{tabular}{|c|c|}
\hline Main subject & Reference \\
\hline $\begin{array}{l}\text { Pedagogical Pat- } \\
\text { terns for Learning } \\
\text { Applications }\end{array}$ & $\begin{array}{l}\text { FIORAVANTI, M. L.; BARBOSA, E. F. A Catalog of Pedagogical Patterns for Learning Applications. In: Proceed- } \\
\text { ings of the 48th Annual Frontiers in Education Conference (FIE 2018), San Jose, USA, } 2018 .\end{array}$ \\
\hline $\begin{array}{l}\text { MLearning-PL } \\
\text { Experimental } \\
\text { Studies }\end{array}$ & $\begin{array}{l}\text { FIORAVANTI, M. L.; OLIVEIRA, C. D.; SCATALON, L. P.; BARBOSA, E. F. An Empirical Investigation on a } \\
\text { Pedagogical Pattern Language for Mobile Learning Applications. In: Proceedings of the 48th Annual Frontiers in } \\
\text { Education Conference (FIE 2018), San Jose, USA, } 2018 \text {. }\end{array}$ \\
\hline MLearning-PL & $\begin{array}{l}\text { FIORAVANTI, M. L.; BARBOSA, E. F. A Pedagogical Pattern Language for Mobile Learning Applications. In: } \\
\text { Proceedings of 24th Conference on Pattern Languages of Programs (PLoP 2017). Vancouver, BC, Canada. } 2017 .\end{array}$ \\
\hline $\begin{array}{l}\text { MLearning Apps } \\
\text { Requirements } \\
\text { Catalog }\end{array}$ & $\begin{array}{l}\text { SOAD, G. W.; FIORAVANTI, M. L.; Falvo Júnior, V.; MARCOLINO, A. S.; Duarte Filho, N. F.; BARBOSA, E. } \\
\text { F. ReqML-Catalog: The Road to a Requirements Catalog for Mobile Learning Applications. In: Proceedings of the } \\
\text { Proceedings of the 47th Annual Frontiers in Education Conference (FIE 2017). Indianapolis, Indiana, USA. } 2017 .\end{array}$ \\
\hline $\begin{array}{l}\text { Pedagogical } \\
\text { Pattern Language } \\
\text { Tool }\end{array}$ & $\begin{array}{l}\text { SILVA, J. M.; BARBOSA, E. F.; FIORAVANTI, M. L.; FASSBINDER, A. G. O. Uma Ferramenta de Apoio ao } \\
\text { Gerenciamento de Padrões para Propósitos Pedagógicos. In: Anais dos Workshops do VI Congresso Brasileiro de } \\
\text { Informática na Educação (WCBIE 2017). Recife, Pernambuco, Brasil. } 2017 .\end{array}$ \\
\hline $\begin{array}{l}\text { SMS on Peda- } \\
\text { gogical Patterns }\end{array}$ & $\begin{array}{l}\text { FIORAVANTI, M. L.; BARBOSA, E. F. A Systematic Mapping on Pedagogical Patterns. In: Proceedings of the } \\
\text { 46th Annual Frontiers in Education Conference (FIE 2016). Erie, Pennsylvania, USA. } 2016 .\end{array}$ \\
\hline $\begin{array}{l}\text { SMS on Learning } \\
\text { Applications }\end{array}$ & $\begin{array}{l}\text { FIORAVANTI, M. L.; MOREIRA, R. B.; BARBOSA, E. F. Utilização de Padrões no Ciclo de Vida de Aplicações } \\
\text { de Aprendizagem: Um Mapeamento Sistemático. In: Proceedings of the XXVI Brazilian Symposium on Computers } \\
\text { in Education (SBIE 2015). Maceió, Alagoas, Brasil. 2015. }\end{array}$ \\
\hline
\end{tabular}


VII Congresso Brasileiro de Informática na Educação (CBIE 2018)

Anais dos Workshops do VII Congresso Brasileiro de Informática na Educação (WCBIE 2018)

Other contributions of this Master's research are the following: (i) Characterization of the state-of-the-art on the use of patterns in learning applications by means of a systematic mapping; (ii) Characterization of the state-of-the-art of the pedagogical patterns reported in the literature by means of a systematic mapping; (iii) Proposal of a requirements catalog to characterize pedagogical requirements of mobile learning; and (iv) Experimental evaluation of MLearning-PL by means of two experimental studies.

We identified several possibilities of continuity of the work undertaken in this Master's research and future directions for research, namely: (i) Evolution of MLearningPL, either by adding more pedagogical patterns in the literature to MLearning-PL or by rewriting the patterns in a more verbose format to suit different readers' preferences; (ii) Development of mobile learning applications to assess the applicability of MLearning-PL in a real context; (iii) Conduction of more evaluations; and (iv) Development of a pedagogical pattern repository to make pedagogical patterns and pattern languages available.

\section{Acknowledgements}

This study was financed by the University of São Paulo (USP) and the Brazilian funding agencies: Coordenação de Aperfeiçoamento de Pessoal de Nível Superior - Brasil (CAPES) - Finance Code 001/Procad 071/2013, CNPq and FAPESP.

\section{References}

Bergin, J., Eckstein, J., Volter, M., Sipos, M., Wallingford, E., Marquardt, K., Chandler, J., Sharp, H., and Manns, M. L. (2012). Pedagogical Patterns: Advice For Educators. Joseph Bergin Software Tools.

Braga, R. T. V., Ré, R., and Masiero, P. C. (2007). A Process to Create Analysis Pattern Languages for Specific Domains. In Proceedings of SugarLoafPLoP, volume 2007.

Costabile, M. F., De Angeli, A., Lanzilotti, R., Ardito, C., Buono, P., and Pederson, T. (2008). Explore! Possibilities and Challenges of Mobile Learning. In Proceedings of the SIGCHI Conference on Human Factors in Computing Systems, CHI '08, pages 145-154, New York, NY, USA. ACM.

Craig, A., Coldwell-Neilson, J., Goold, A., and Beekhuyzen, J. (2012). A review of elearning technologies-opportunities for teaching and learning. In CSEDU 2012-4th International Conference on Computer Supported Education, pages 29-41. [INSTICC].

Economides, A. A. (2008). Requirements of mobile learning applications. International Journal of Innovation and Learning, 5(5):457-479.

Fioravanti, M. L. (2017). MLearning-PL: a pedagogical pattern language for mobile learning applications. Master's thesis, Institute of Mathematics and Computer Science - ICMC/USP, São Carlos, SP. Availabe at http: / / www.teses.usp.br/ teses/disponiveis/55/55134/tde-06072018-102108/.

Fioravanti, M. L. and Barbosa, E. F. (2016). A Systematic Mapping on Pedagogical Patterns. In Proceedings of the 46th Annual Frontiers in Education Conference (FIE 2016), Erie, Pennsylvania, USA.

Fioravanti, M. L. and Barbosa, E. F. (2018). A Catalog of Pedagogical Patterns for Learning Applications. In Proceedings of the 48th Annual Frontiers in Education Conference (FIE 2018), San Jose, USA. 
VII Congresso Brasileiro de Informática na Educação (CBIE 2018)

Anais dos Workshops do VII Congresso Brasileiro de Informática na Educação (WCBIE 2018)

Fioravanti, M. L., Moreira, R. B., and Barbosa, E. F. (2015). Utilização de Padrões no Ciclo de Vida de Aplicações de Aprendizagem: Um Mapeamento Sistemático. In Proceedings of the XXVI Brazilian Symposium on Computers in Education (SBIE 2015), Maceió, Alagoas, Brasil.

Gamma, E., Helm, R., Johnson, R., and Vlissides, J. (1995). Design Patterns: Elements of Reusable Object-oriented Software. Addison-Wesley, Boston, MA, USA.

Iba, T., Miyake, T., Shimonishi, K., Kato, T., Kobayashi, Y., Yotsumoto, N., Hanabusa, M., Iida, M., and Sakamoto, M. (2014). Learning Patterns: A Pattern Language for Creative Learning. 1. CreativeShift Lab, 1 edition.

Iba, T., Sakamoto, M., and Miyake, T. (2011). How to Write Tacit Knowledge as a Pattern Language: Media Design for Spontaneous and Collaborative Communities. ProcediaSocial and Behavioral Sciences, 26:46-54.

Kearney, M., Schuck, S., Burden, K., and Aubusson, P. (2012). Viewing mobile learning from a pedagogical perspective. Research in Learning Technology, 20(0).

Lonsdale, P., Baber, C., Sharples, M., Byrne, W., Arvanitis, T. N., Brundell, P., and Beale, R. (2005). Context awareness for MOBIlearn: creating an engaging learning experience in an art museum. Mobilelearning anytimeeverywhere, 115.

Meszaros, G. and Doble, J. (1997). A Pattern Language for Pattern Writing. AddisonWesley Software Pattern Series, pages 529-574.

Petersen, K., Feldt, R., Mujtaba, S., and Mattsson, M. (2008). Systematic mapping studies in software engineering. In Proceedings of the 12th International Conference on Evaluation and Assessment in Software Engineering, EASE'08, pages 68-77, Swinton, UK, UK. British Computer Society.

Pressman, R. and Bruce R. Maxim, D. (2014). Software Engineering: A Practitioner's Approach. McGraw-Hill Education.

Sarrab, M., Al-Shihi, H., and Rehman, O. (2013). Exploring Major Challenges and Benefits of M-learning Adoption. British Journal of Applied Science \& Technology, $3(4): 826-839$.

Sharples, M. (2013). Mobile learning: research, practice and challenges. Distance Education in China, 3(5):5-11.

Skiba, D. J. (2011). On the HorizonMobile Devices: Are They a Distraction or Another Learning Tool? Nursing education perspectives, 32(3):195-197.

Soad, G. W., Fioravanti, M. L., Falvo Júnior, V., Marcolino, A. S., Duarte Filho, N. F., and Barbosa, E. F. (2017). ReqML-Catalog: The Road to a Requirements Catalog for Mobile Learning Applications. In Proceedings of the 47th Annual Frontiers in Education Conference (FIE 2017), Indianapolis, Indiana, USA.

Svetlana, K. et al. (2009). Adaptation e-learning contents in mobile environment. In Proceedings of the 2 nd International Conference on Interaction Sciences: Information Technology, Culture and Human, pages 474-479. ACM.

Wohlin, C., Runeson, P., Höst, M., Ohlsson, M. C., Regnell, B., and Wesslén, A. (2012). Experimentation in software engineering. Springer Science \& Business Media. 